Rev. Téc. Ing. Univ. Zulia. Vol. 42, No. 1, 2019, 10-17

\title{
Cu (II) Chemisorption on Calcined Substrates made with an Oxidic Refractory Variable Charges Lithological Material
}

\author{
Fernando Millán ${ }^{1 *} \mathbb{D}$,José G. Prato ${ }^{2,3} \mathbb{D}$, Luisa Carolina González ${ }^{4}$, Andrés Márquez ${ }^{1}$ D \\ Pablo Djabayan $^{5}$ (D) \\ ${ }^{1}$ Polythecnic Institute "Santiago Mariño" IUPSM-Mérida, Venezuela, Chemical Engineering School, \\ ${ }^{2}$ Universidad Nacional de Chimborazo (Unach), Facultad de Ingeniería, Riobamba, Ecuador. \\ ${ }^{3}$ Los Andes University, (ULA), Chemical Engineering School, Mérida, Venezuela. \\ ${ }^{4}$ Universidad Nacional de Chimborazo (Unach), Facultad de Ciencias de la Salud, Carrera Laboratorio Clínico e \\ Histopatológico, Riobamba, Ecuador. \\ ${ }^{5}$ Universidad Nacional de Chimborazo (Unach), Facultad de Ciencias de la Salud, Medicina, Riobamba, Ecuador \\ *Autor de Contacto: fcarlosmillan@gmail.com, pratoj@gmail.com \\ https://doi.org/10.22209/rt.v42n1a02 \\ Recepción: 01/03/2018 | Aceptación: 20/10/2018 | Publicación: 31/12/2018
}

\begin{abstract}
This work presents a complementary study on the nature of copper ions adsorption reaction on calcined substrates with variable charge surfaces prepared with refractory lithological materials obtained from San Juan de Lagunillas, near the city of Mérida, Mérida State, Venezuela. The study was performed on activated and non-activated calcined substrate, prepared with granulometric fraction between $425 \mathrm{~mm}-250 \mathrm{~mm}$. The results of the PZC showed that thermal treatment favors the formation of amphoteric oxides with $\mathrm{pH}_{0} 6-7$ similar to those reported in the literature. Although the isotherms obtained in previous experiments are $L$ type which indicative of strong affinity of copper ions with the surfaces of the substrates, they do not represent an absolute proof about a chemosorption reaction. This kind of adsorption reaction should produce $\mathrm{H}_{3} \mathrm{O}^{+}$ ion that acidifies the solution. The adsorption experiment performed on $2 \mathrm{~g}$ of calcined substrates with solutions of 0.001 , 0.01 and $0.1 \mathrm{M} \mathrm{Cu}^{+2}$ produced $0.11,0.27$ and $1.19 \mathrm{mmol}$ of protons ions respectively. These data complement the information given by the isotherms about the chemisorption of copper ions with the surface of this calcined substrate, confirming the specific adsorption.
\end{abstract}

Keywords: Adsorption; lithological materials; variable charge surface; cupper ion.

\section{Quimioadsorción de Cu (II) sobre un Sustrato Calcinado preparado con un Material Litológico Refractario de Carga Variable}

\begin{abstract}
Resumen
Este trabajo presenta un estudio complementario sobre la naturaleza de la reacción de adsorción de iones cobre sobre la superficie de carga variable de sustratos calcinados preparados a partir de materiales litológicos refractarios obtenidos de San Juan de Lagunillas, Mérida, Venezuela. El estudio se realizó sobre sustrato calcinado activado y no activado, preparado a partir de la fracción granulométrica entre 425 y $250 \mathrm{~mm}$. Los resultados del experimento de PCC mostraron que el tratamiento térmico favorece la formación de óxidos anfóteros con $p \mathrm{H}_{0}$ entre 6 y 7 similares a los reportados en la literatura. Aunque las isotermas obtenidas en estudios previos son de tipo $L$ indicativas de una fuerte afinidad de iones $\mathrm{Cu}^{+2}$ con las superficies de los sustratos, no representan una prueba absoluta sobre una reacción de quimioadsorción. Este tipo de reacción tiene asociada la producción de protones que acidifican la solución. Los experimentos de adsorción realizados sobre $2 \mathrm{~g}$ de sustrato calcinado con soluciones de 0,001, 0,01 y 0,1 M de iones cobre producen 0,11, 0,27 y 1,19 mmol de protones respectivamente. Estos datos complementan la información de las isotermas a favor de una quimioadsorción de los iones cobre con la superficie del sustrato calcinado, lo que confirma la adsorción específica.
\end{abstract}

Palabras clave: Adsorción; materiales litológicos; superficie de carga variable; iones cobre. 


\section{Introduction}

Transitional metal adsorption in variable charge soils have been well studied by several authors [1,2] but has not been treated for the case of calcined substrates prepared with oxidic refractory lithological materials. In both cases the $\mathrm{Fe}$ and $\mathrm{Al}$, as well as $\mathrm{Mn}$ and $\mathrm{Ti}$ amphoteric oxides are the most important source of variable charge; these amphoteric surfaces can be either protonated or deprotonated by acid or alkaline treatment to create positive or negative charges on the oxides surfaces, leading to cation and anion adsorption reactions respectively, according to equation (1) [3].

$$
>[M-O H]^{-1 / 2} \stackrel{+}{\stackrel{H^{+}}{\leftrightarrow}}>\left[M-O H_{2}\right]^{+1 / 2}
$$

The literature also suggest a mechanism for which the adsorption of transitional metals on these kind of surfaces, through the formation of a covalent bond between the metal ion and the oxidic surface, called chemisorption, according to equation (2) where M could be any transitional metal. model described above, H30+ ion must be one of the reaction products, producing acidification in the solution. Therefore, by following up the $\mathrm{pH}$ evolution during the adsorption reaction it should show this acidification process.

\section{Experimental Section}

Geografic localization and characterization of the lithologic material have been described in the literature [7]. Being an arid zone, the soils are classified as aridisols [12], presenting serious limitations for agronomical uses. However, some of these lithological materials are used by potters for making kitchen hardware and constructions materials like bricks and crockery using thermal treatment due to its refractory properties. Calcined subtrates were prepare according to the procedure described in the literature [4 - 6], so by using the granulometric fraction between 425 - $250 \mathrm{~mm}$ for the determination of the zero charge point, the $\mathrm{pH}$ and the electrical conductivity measurements. The specific surface was measured by the BET technique using isothermal $\mathrm{N}_{2}$ adsorption. The procedure for the deprotonation reaction of the calcined substrate (substrate activation) is also described in the same literature were the substrate is chemically treated

$$
>\mathrm{Fe}-\mathrm{OH}^{-1 / 2}+\mathrm{M}\left(\mathrm{H}_{2} \mathrm{O}\right)_{6}^{+n} \rightarrow>\mathrm{Fe}-\mathrm{O}-\mathrm{M}\left(\mathrm{H}_{2} \mathrm{O}\right)_{5}^{+((n-3) / 2)}+\mathrm{H}_{3} \mathrm{O}^{+}
$$

Such kind of reaction modifies the surface charge through more positive values, which allows anion adsorption, and produces acidification through the formation of $\mathrm{H} 3 \mathrm{O}+$ ion. This process is defined as specific adsorption or chemisorption, which has the tendency to be irreversibility. In previous publications $[4,5]$ copper adsorptions on calcined substrates prepared with some of these refractory lithologic materials which have surface variable charges were described. This physicochemical characteristic is due to the presence of amphoteric oxides in the material, such as $\mathrm{Fe}, \mathrm{Al}, \mathrm{Mn}$ and $\mathrm{Ti}$, previously described in the literature [6, 7]. As a consequence of these particular properties, these lithological materials are versatile for preparing calcined adsorbing substrates and their applications in water treatment. Furthermore, due to their capacity for anion/cation exchange, heavy metals, oxyanions and organic matter are removed by adsorption processes. In previous publications the application to water softening [8], cation adsorption reactions [4], anion adsorption reactions $[9,10]$ and water treatment $[11]$ have been described. The objective of this paper is to complement the information presented by the previous articles with new findings which support the hypothesis of the chemisorption of cupper ions on the oxidic surface of these calcined substrates, in order to continue working on this project. Moreover, according to the theoretic with a $\mathrm{NaOH} 0.1 \mathrm{M}$ solution during $12 \mathrm{~h}$ and finally the excess of alkali is wash out with distillate water until it reaches $\mathrm{pH} 7$, and later it dries in a furnace at $120^{\circ} \mathrm{C}$. The determination of Point of Zero Charge (PZC) of raw the material, (RM), calcined non-activated (NAS) and activated substrates (AS) was performed according to the method described by the literature $[13,14]$. The $p \mathrm{H}$ was measured at different ionic strength against $p \mathrm{H}$ in aqueous extract and $p \mathrm{H}_{0}$ was recorded on a graphic of $\Delta p \mathrm{H}$ against $p \mathrm{H}_{\mathrm{H} 2 \mathrm{O}}$ which gives de $p \mathrm{H}_{\mathrm{o}}$ at the intersection of $p \mathrm{H}_{\mathrm{H} 2 \mathrm{O}}$ axe. The adsorption study was performed by triplicate, in isothermal conditions at $20 \pm 2{ }^{\circ} \mathrm{C}$ for $24 \mathrm{~h}$, using batch equilibration procedure by treating $2 \mathrm{~g}$ of calcined substrate with $5,10,15,20,25,30$ and $40 \mathrm{~mL}$ of $0.001 \mathrm{M} \mathrm{Cu}^{+2}$, in closed vessels. Then the $\mathrm{Cu}^{+2}$ equilibrium concentration were determined by the complexometric titration at $p \mathrm{H} 10$ with a $0.001 \mathrm{M}$ EDTA standard solution and NET as metalochromic indicator. Thus, adsorption isotherms were obtained by plotting the amount of copper adsorbed (mmol g-1 substrate) against the equilibrium concentration (mmol) and fitted to the linear form of the Langmuir equation [15-17]. The $p \mathrm{H}$ and the EC variations were measured using the same batch equilibration procedure, in triplicate samples, by treating $2 \mathrm{~g}$ of raw material, activated and non-activated calcined substrate, with increasing volume of $0.001 \mathrm{M}, 0.01 \mathrm{M}$ and $0.1 \mathrm{M}$ of 
$\mathrm{Cu}^{+2}$ solutions. Suspensions were periodically shaken at 20 $\pm 2{ }^{\circ} \mathrm{C}$ for $24 \mathrm{~h}$ in $100 \mathrm{~mL}$ glass beakers. $p \mathrm{H}$ was measured with a Hanna $211 p$ Hmeter, calibrated with commercial buffer solutions of pH 4 and 7. Electrical Conductivity was measured with a Trans Instrument HC3010 Conductimeter, calibrated with standard reference.

\section{Results and Discussion}

\section{Determination of surface zero charge point}

Amphoteric oxides have surface charges that are $p \mathrm{H}$ dependent; they react in alkaline or acid medium to create negative or positive charges which are responsible for the cation or anion adsorption reactions. So, the $p \mathrm{H}$ value at which surface positive charge equals to the surface negative charge is called the point of zero charge, $\mathrm{PZC}$ or $p \mathrm{H}_{0}$ [18]. Figure 1 shows the results of the potentiometric titration on the raw material as well as on the nonactivated activated substrates. The intersection of the curves with the $p \mathrm{H}_{\mathrm{H} 2 \mathrm{O}}$ axis shows the $p \mathrm{H}$ value when the surface diffuses electrical charge equals to zero, indicating the PZC. All the curves present a single intersection point; therefore the PZC is defined by a unique $p \mathrm{H}$ value. For the raw material PZC is around 6 however, the $\Delta p \mathrm{H}$ values are positive indicating that the surface charges are basically negative. However, in the case of calcined substrates surface charges varies according to the solution $p \mathrm{H}$, indicating that the thermal treatment favors the formation of amphoteric oxides.

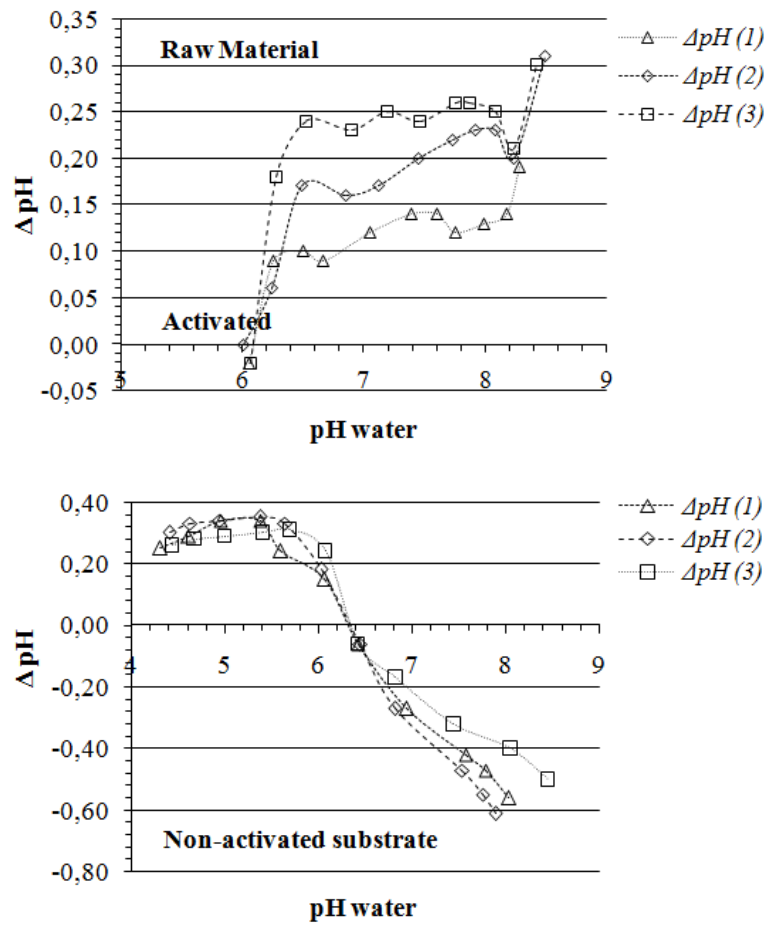

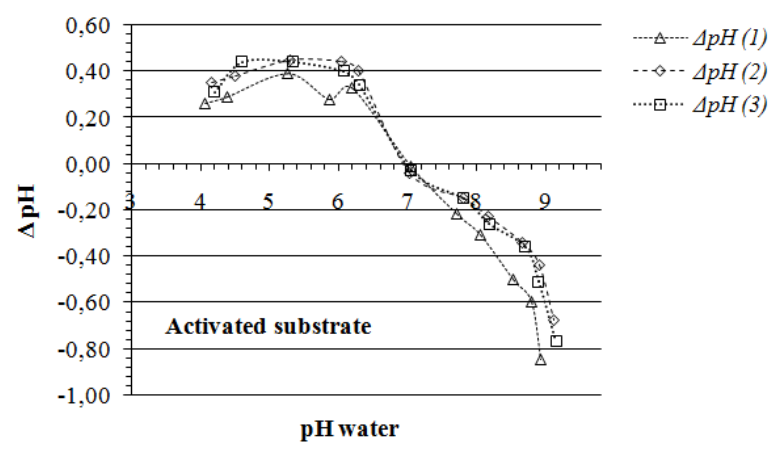

Figure 1. Potentiometric titrations for the determination of zero-point charge (ZPC) in raw material, non-activated and activated substrates.

The PZC values for the calcined substrates lies between 6 and 7.2 and the PZC in calcined substrates shifts from 6.4 to 7 because of the alkaline treatment which creates a greater negative charge density on the substrate surface due to the oxides deprotonation reaction. The range in which the PZC of the raw material and the calcined substrates lies is similar to the PZC values for pure $\alpha-\mathrm{Fe}_{2} \mathrm{O}_{3}$, goethite and gibbsite [19]. Moreover, the differences with these experimental values are probably are due to a mixture of amorphous variable charge oxides in the material. In reality, minerals and clays are rarely found in soils as pure mineral because particles can be formed of stratified layers of different mineral phases; clays could also be deeply associated with oxides and the amorphous material, making particular identification of minerals very difficult. Although it has been reported that mixing clays and minerals are very common in many types of soils [12].

\section{Adsorption isotherm}

Adsorption of copper ions takes place on active sites where amphoteric oxides are deprotonated, creating negative charges not only on non-activated but also in activated surface. Figure 2 shows the adsorption isotherm of $\mathrm{Cu}^{+2}$ on adsorbent substrate activated with $0.10 \mathrm{~N} \mathrm{NaOH}$ and non-activated. As it was pointed out in a previous paper [5], the $L$ type isotherm indicates great affinity between copper ions and the substrate's surface with the formation of a saturated monolayer of copper ions on the surface bounded probably through an inner sphere complex, as is predicted by the Langmuir model. The activated substrate enhances the adsorption reaction due to the grater negative charge density created after oxides deprotonation through alkaline treatment. The Isotherm profiles obtained from copper ions adsorption are similar to those reported from the $\mathrm{Cu}^{+2}$ adsorption on goethite and $\gamma-\mathrm{Al}_{2} \mathrm{O}_{3}$, and $\mathrm{TiO}_{2}$ surfaces, confirming specific adsorption or chemisorption between $\mathrm{Cu}^{+2}$ ions and oxide surface [20, 21]. The mechanism reported suggests the acidification of solution by the formation of $\mathrm{H}_{3} \mathrm{O}^{+}$ions, which is showed by the $\mathrm{pH}$ measurement in different experimental conditions. 


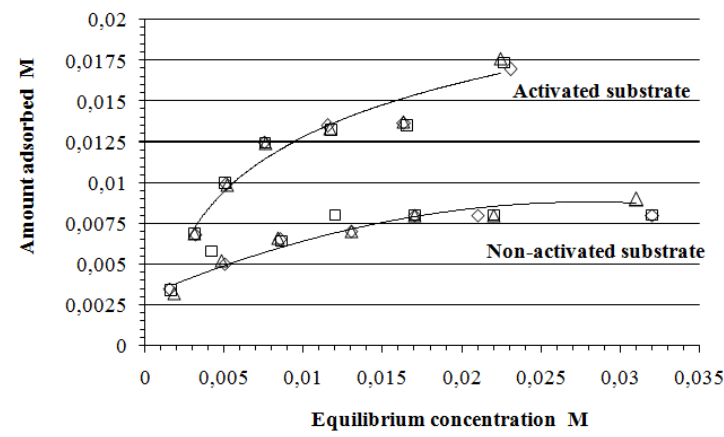

Figure 2. Adsorption isotherms obtained from copper ions adsorption reaction on calcined substrate prepared with the granulometric fraction between $425-250 \mathrm{~mm}$.

The adjustments to the Langmuir model was presented in the literature cited above [5] showing a good linear correlation and little average difference between experimental and calculated values. Table 1 shows the fitted equations and $\mathrm{K}$ values obtained for the adsorption reaction on the activated and non-activated substrate prepared with the granulometric fraction between 425 $250 \mu \mathrm{m}$. The constant $\mathrm{K}_{2}$ which defines the straight line slope is greater for the case of adsorption reaction on the activated substrate which agrees with the information given by the isotherm in the Figure 1. itself the real interaction between copper ions and the substrate surface.

\section{pH study}

The information given by the isotherm graph and the fitting equations to the Langmuir model is insufficient to confirm the hypothesis of a chemisorption reaction between copper ions and substrate surface. The theoretical model for the specific adsorption or chemisorption type reaction between transitional metals and amphoteric oxides, described by equation (2), suggests the production of $\mathrm{H}_{3} \mathrm{O}^{+}$ions during the adsorption reaction. Therefore, the $p \mathrm{H}$ measurement should provide the evidence of an acidifying process during the adsorption reaction. Figure 3 shows the $p \mathrm{H}$ variation, by triplicating the measurement, during the adsorption process as a function of $\mathrm{mmol}$ of $\mathrm{Cu}^{+2}$ ions, added from a solution $0.001 \mathrm{M}$, to the raw material, and calcined activated and non-activated substrate. In all cases, copper adsorption reaction produces acidification of the solution, because of $\mathrm{H}_{3} \mathrm{O}^{+}$ion production. However, acidification in the solution is more accentuated in the non-activated and activated substrates. The smaller acidification in the raw material has to be related to the smaller density of negative charges in the surface material.

Table 1. Fitted equation, correlation coefficients and $K_{1}$ and $\mathrm{K}_{2}$ values, corresponding to the adsorption isotherm obtained from copper ions adsorption on calcined substrate

\begin{tabular}{ccccc}
\hline Substrate & Fitted equation & $r$ & $K_{1}$ & $K_{2}$ \\
\hline NAS & $C_{\text {eq }} / \mathrm{x} / \mathrm{m}=0.4850+230.31 C_{\text {eq }}$ & 0.9977 & 474.86 & 0.0043 \\
AS & $C_{\mathrm{eq}} / \mathrm{x} / \mathrm{m}=0.5703+98.21 C_{\mathrm{eq}}$ & 0.9868 & 172.20 & 0.0102 \\
\hline
\end{tabular}

However, isotherm may show but does not confirm information about the interaction between $\mathrm{Cu}^{+2}$ ions and calcined substrate surface; neither does the FTIR spectra [5]. Nevertheless, $L$ type isotherm is indicative of great affinity between copper ions and calcined substrate surfaces. Likewise, according to the literature, in a chemisorption reaction transitional metals should bond to the amphoteric surface through to the formation of a covalent bonding in an innersphere complex in which the metal becomes part of the oxide surface structure, according to the reaction 2 in which $\mathrm{H}_{3} \mathrm{O}^{+}$ions are ones of the reaction products which acidifies the solution [3]. Unfortunately, the isotherm doesn't explain the production of $\mathrm{H}_{3} \mathrm{O}^{+}$ion during the adsorption reaction and cannot explain by

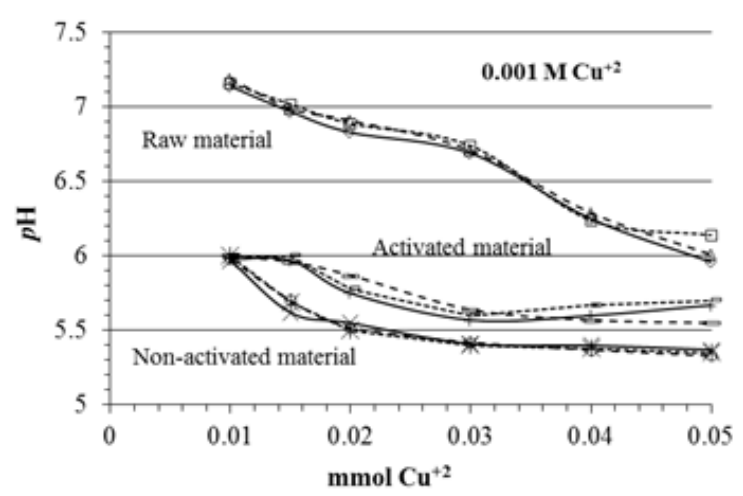

Figure 3. $p \mathrm{H}$ variation, of the triplicated measurement, as a function of $\mathrm{mmol}$ of $\mathrm{Cu}^{+2}$ ions added to the raw material, and calcined activated and non-activated substrate. Dotted, dashed and continued lines represent the three replicates measurements. 
Figure 4 shows the $p \mathrm{H}$ variation, by triplicated measurements, as a function of $\mathrm{mmol}$ of $\mathrm{Cu}^{+2}$ added to the activated calcined substrate. The three graphics correspond to the adsorption reaction with the $0.001 \mathrm{M}, 0.01 \mathrm{M}$, and 0.1 $\mathrm{M} \mathrm{Cu}^{+2}$ solutions used for the experiment. All curves show an evident acidification of the solution, indicating once again the production of $\mathrm{H}_{3} \mathrm{O}^{+}$ions during the adsorption reaction. Consequently, solutions become more acidic as the copper ion concentration increase. Table 2 shows the mmol of $\mathrm{H}^{+}$ions produced at the beginning and at the end of the adsorption experiment for the conditions described in Figures 3 and 4. In all cases the final concentration of $\mathrm{H}^{+}$ions is at least 10 times greater in relation to the initial concentration, but also the greater the copper concentration is, the more acidic the solution become. The net acidification for the three experimental condition described in the Figure 4 are equivalent to $0.11,0.27$ and $1.19 \mathrm{mmol}$ of $\mathrm{H}^{+}$ions, respectively.
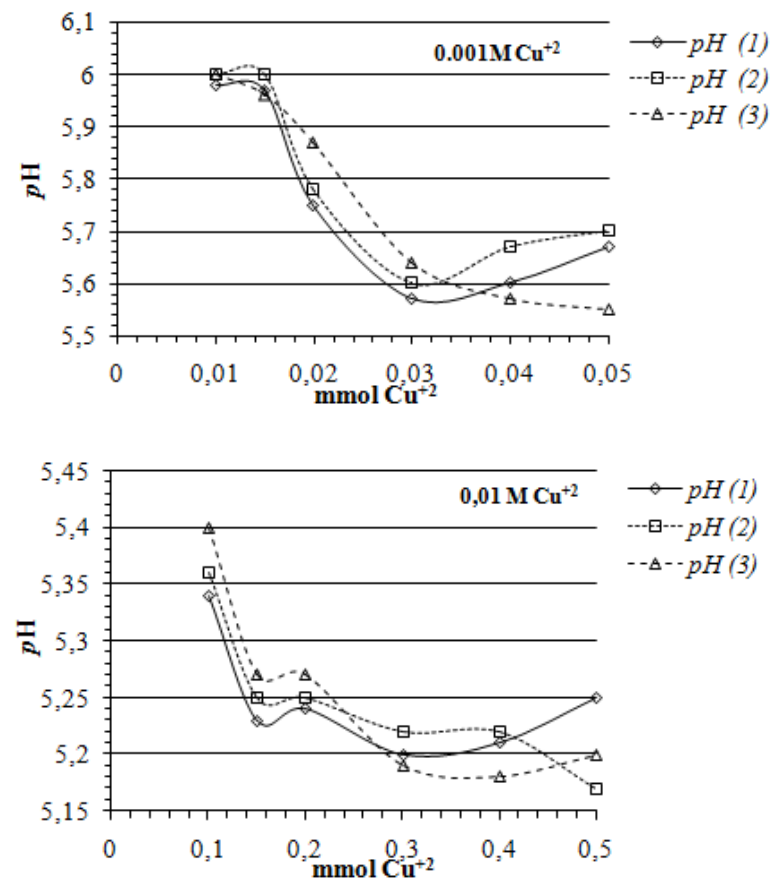

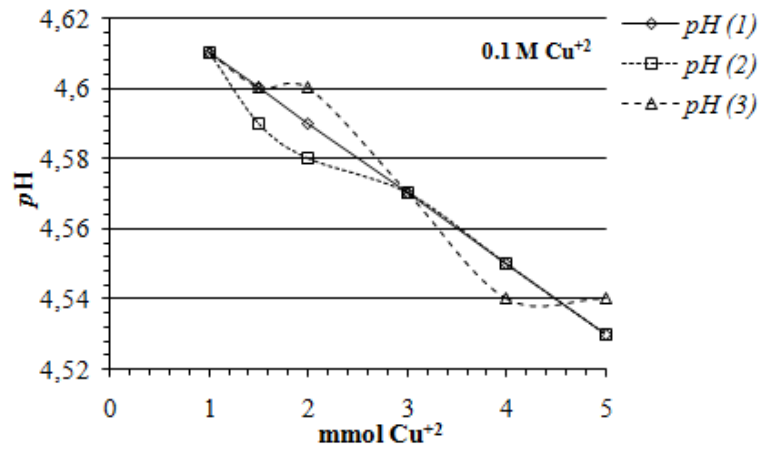

Figure 4. $\mathrm{pH}$ variation, of the triplicate measurement, as a function of mmol of $\mathrm{Cu}+2$ ion added to the calcined substrate, activated in alkaline medium. Dotted, dashed and continued lines represent the three replicates measurements.

According to the information given by the isotherm graph and the $p \mathrm{H}$ study, it can be suggested that the interaction between copper ions and the amphoteric surface of the substrate can be explained by a chemisorption reaction according to the reaction (3):

In any case, the interaction between copper ions and the oxidic surface must be strong enough because attempts for desorption even with strong acid solutions were infructuous.

\section{Electrical conductivity study}

Figure 5 shows the Electric Conductivity (EC) variation as a function of mmol of $\mathrm{Cu}+2$ ions added to the raw material, and calcined activated and nonactivated substrate, using a $0.001 \mathrm{M} \mathrm{Cu}+2$ solution. In all cases EC of the solution decrease due to the adsorption reaction. In the case of the raw material, there is a contribution to the EC from the dissolved fraction in the solution.

Table 2.- $\mathrm{mmol}$ of $\mathrm{H}_{3} \mathrm{O}^{+}$ions produced during the adsorption reaction

\begin{tabular}{ccccc}
\hline $\mathrm{Cu}^{+2} \mathrm{M}$ & mmol H & mmol H $50 \mathrm{~mL}$ soln. & $\mathrm{Net}^{+} \mathrm{mmol} \mathrm{H}^{+}$ & $\mathrm{RED}$ \\
\hline $0.001 / \mathrm{RM}$ & $6.71 \times 10^{-7} \pm 2.39 \times 10^{-8}$ & $4.60 \times 10^{-5} \pm 9.50 \times 10^{-6}$ & $4.59 \times 10^{-5} \pm 9.03 \times 10^{-6}$ & 19.7 \\
$0.001 / \mathrm{NAS}$ & $1.04 \times 10^{-5} \pm 3.60 \times 10^{-7}$ & $2.23 \times 10^{-4} \pm 1.05 \times 10^{-5}$ & $2.13 \times 10^{-4} \pm 1.05 \times 10^{-5}$ & 4.9 \\
$0.001 / \mathrm{AS}$ & $1.02 \times 10^{-5} \pm 2.84 \times 10^{-7}$ & $1.16 \times 10^{-4} \pm 2.30 \times 10^{-5}$ & $1.06 \times 10^{-4} \pm 2.20 \times 10^{-5}$ & 20 \\
$0.01 / \mathrm{AS}$ & $4.31 \times 10^{-5} \pm 3.00 \times 10^{-6}$ & $3.11 \times 10^{-4} \pm 2.87 \times 10^{-5}$ & $2.68 \times 10^{-4} \pm 2.84 \times 10^{-5}$ & 10 \\
$0.1 / \mathrm{AS}$ & $2.78 \times 10^{-4} \pm 2.89 \times 10^{-5}$ & $1.47 \times 10^{-3} \pm 2.31 \times 10^{-5}$ & $1.192 \times 10^{-3} \pm 3.70 \times 10^{-5}$ & 3 \\
\hline
\end{tabular}

$$
>\mathrm{M}-\mathrm{OH}^{-1 / 2}+\mathrm{Cu}\left(\mathrm{H}_{2} \mathrm{O}\right)_{4}^{+2} \rightarrow>\mathrm{M}-\mathrm{O}-\mathrm{Cu}\left(\mathrm{H}_{2} \mathrm{O}\right)_{4}^{+1 / 2}+\mathrm{H}_{3} \mathrm{O}^{+}
$$




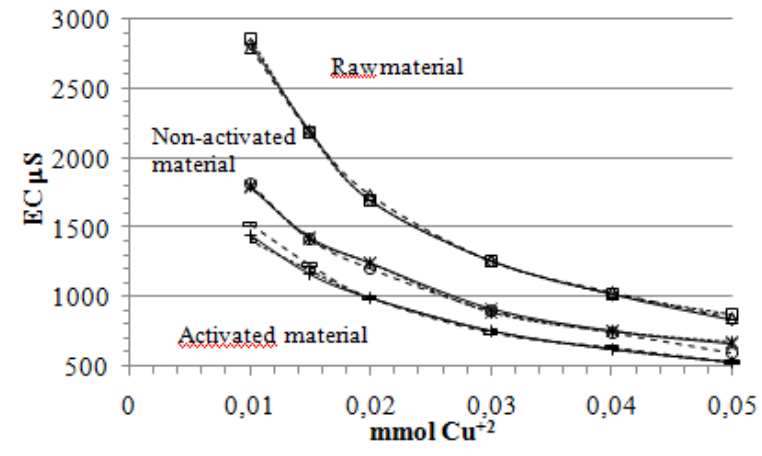

Figure 5. Electric conductivity variation, of the triplicated measurements, as a function of $\mathrm{mmol}$ of $\mathrm{Cu}^{+2}$ ions added,

from a solution $0.001 \mathrm{M}$, to the raw material, and the calcined activated and non-activated substrates. Dotted, dashed and continued lines represent the three replicates measurements.

However, in the case of calcined substrates, the $E C$ relay only on copper and sulphate ions, due to their greater concentration, other ionic species coming from the calcined substrate has minor contribution because calcined substrate is slightly soluble, so the dissolved fraction is negligible. On the other hand, the adsorption reaction on activate and non-activated substrates seems to take place by the same mechanism, but it is produced in a greater extend on activated material due to the creation of new activated sites through the deprotonation reaction. This aspect was also evidenced by the isotherms and Langmuir constants. The lowest $E C$ values during adsorption reaction on activated substrate in relation to non-activated substrate shows that adsorption reaction actually takes place more extensively on this substrate.

Figure 6 shows the average quantities of copper ions adsorbed on $2 \mathrm{~g}$ of raw material and $2 \mathrm{~g}$ of the activated and non-activated calcined substrate. These quantities are similar to those reported in previous experiment [5] and confirm that the surface activation reaction creates a greater negative charge density on the surface were the adsorption reaction may occur. The greater adsorption on the raw material is due to the greater specific surface that reacts, and the lowest adsorption on calcined substrates shows that calcination process affects the net surface available for the adsorption reaction [11]. Table 3 present specific surface data for raw material and calcined substrate; according to these results, specific surface of calcined substrate decreases about $55 \%$ in relation with raw material. However, these values could be underestimated because the limitations of $\mathrm{N}_{2}$ adsorption method, when applied to charged surfaces with specific surfaces of about $10 \mathrm{~m}^{2} / \mathrm{g}$, due to the nonpolarity of $\mathrm{N}_{2}$ molecule [11].

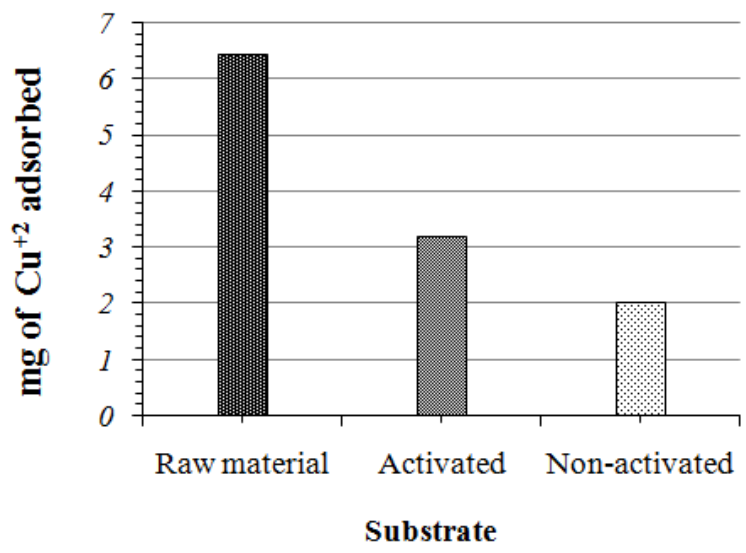

Figure 6. Amount of copper ions, in $\mathrm{mg}$, adsorbed on 2 $\mathrm{g}$ of the raw material and the calcined substrate, with activated and non-activated surface.

Figure 7 shows Electrical Conductivity (EC) variation, of the triplicated measurements, as a function of mmol of $\mathrm{Cu}^{+2}$ solutions added to the calcined substrate, activated in alkaline medium. The three graphics correspond to the $0.001 \mathrm{M}, 0.01 \mathrm{M}$, and the $0.1 \mathrm{M} \mathrm{Cu}^{+2}$ solutions used for the experiment. The EC decreases because of the adsorption reaction which is better defined at lower concentration where the $E C$ decreases to 900 $\mathrm{mS}$ during the reaction, instead of $700 \mathrm{mS}$ where the $\mathrm{Cu}^{+}$ ${ }^{2}$ concentration is ten times greater and $150 \mathrm{mS}$ when the concentration is 100 times greater.
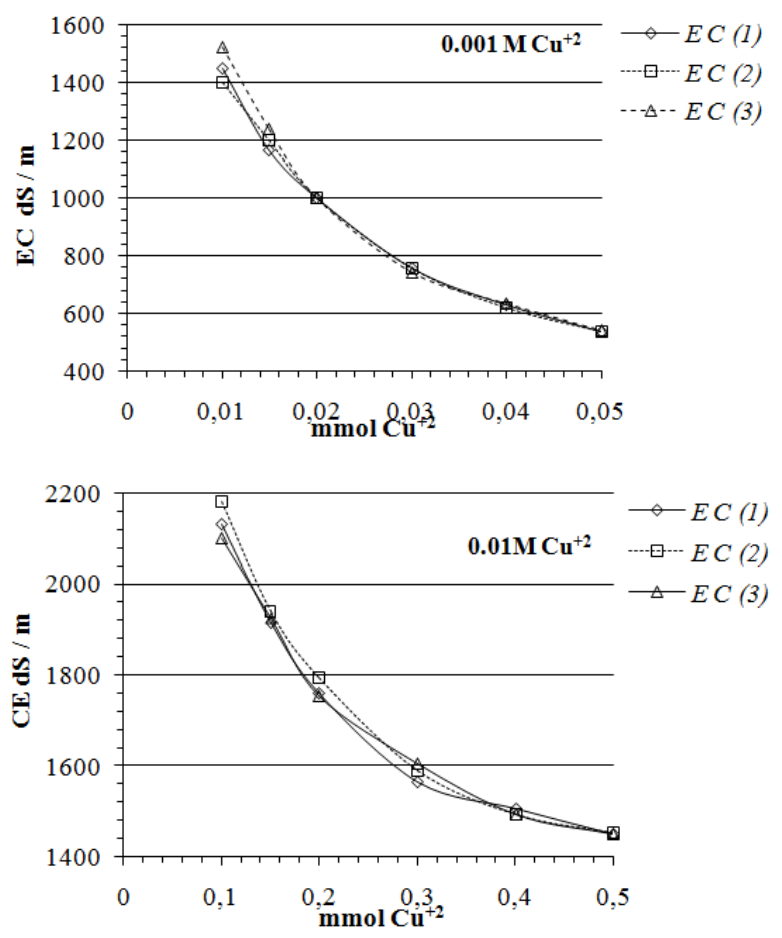


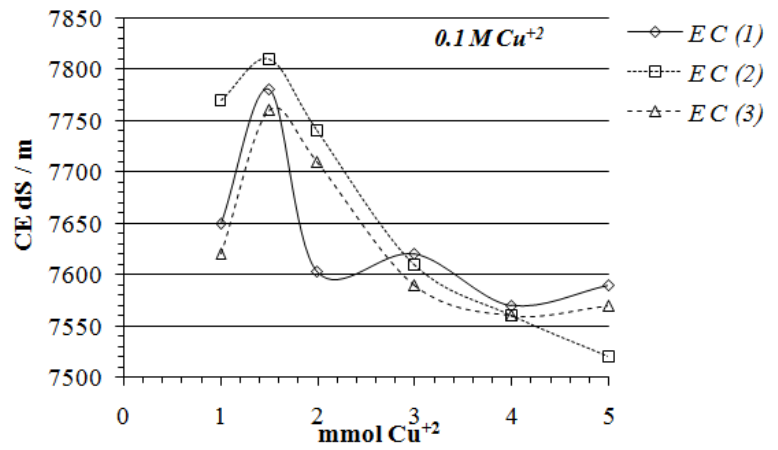

Figure 7. Electrical conductivity variation as a function of mmol of $\mathrm{Cu}^{+2}$ ions added to the calcined substrate. Dotted, dashed and continued lines represent the three replicates measurements. however, the adsorption reaction is better defined at low concentration. The hypothesis of the chemisorption reaction is also supported by the resistance of copper ions to desorption reaction. This fact could be interpreted in terms of a covalence formation between copper ions and the calcined substrate in specific adsorption reaction. It is expected that other transitional metals can suffer such kind of reaction on the surface of these kinds of substrates, and it is possible to separate it from the contaminated waters during a filtration process in a granular media. The variable charge properties of the oxidic surface is evidenced not only by the PZC experiment, but also by the activation reaction, which creates new negative charges that can participate in the adsorption phenomena, thus improving the efficiency of calcined adsorbent substrate for ionic retention. The amphoteric metallic oxides deprotonate in alkaline medium, increasing negative

Table 3. - Specific surface data for raw material and calcined substrate.

\begin{tabular}{ccc}
\hline & Raw material & Calcined substrate \\
\hline Pore superficial área $\left(\mathrm{m}^{2} / \mathrm{g}\right)$ & 56.35 & 20.51 \\
Pore volumen $(\mathrm{mL} / \mathrm{g})$ & 85.80 & 46.30 \\
External Surface $\left(\mathrm{m}^{2} / \mathrm{g}\right)$ & 68.17 & 23.60 \\
BET specific surface $\left(\mathrm{m}^{2} / \mathrm{g}\right)$ & 77.91 & 21.05 \\
\hline
\end{tabular}

\section{Conclusions}

The objective of this study is to take advantage of the physicochemical characteristics of the lithologic material found in the town of San Juan de Lagunillas, Mérida, Venezuela and uses it for the preparation of a calcined substrate that can be applied as a granular media for heavy metal retention in water treatment. Although more studies are required, the results obtained from previous works have shown that the lithologic material is appropriate for the preparation of ionic adsorbent substrates and their application in copper retention from aqueous solutions. Some of these results have shown great affinity between metal ion and adsorbent calcined surface characterized by an $L$ type isotherm, and associated to chemisorption reaction between adsorbate and adsorbent. The mechanism of copper adsorption on oxidic surface seems to be the same for activated and non-activated surfaces however, the differences is given by the greatest density of negative charges created by the alkaline treatment, which deprotonates amphoteric oxides, enhancing adsorption reaction. Nevertheless, this evidence had to be complemented with additional data by proving the associated production of $\mathrm{H}_{3} \mathrm{O}^{+}$ion to such kind of reaction. The $p \mathrm{H}$ measurements during the adsorption reaction showed a significant acidification along the reaction, which validates the literature about transitional metals chemisorption on amphoteric surface with variable charges. This acidification process became more intense as the concentration of copper ions in the solution increases; charge density on calcined adsorbent surface. The thermal treatment favors the formation of the amphoteric oxides with PZC similar to the reported values for pure Fe and $\mathrm{Al}$ oxides. The deprotonation reaction of the reactive groups in the substrate surface have been also proved by the EC measurements, showing that adsorption phenomenon is enhanced on activated surfaces with alkaline treatment just because Copper ions adsorb irreversibly on the amphoteric surface being unable to participate as mobile ions in the solution.

\section{References}

[1] Xu, R. K, Qafoku, N. P., Van Ranst, E., Li, J. Y. and Jiang, J.: "Adsorption properties of subtropical and tropical variable soils: Implication from climate change and biochard amendment". In: Donald Sparks, editors: Advances in Agronomy, Vol. 135, chapter one, p 1 58. Academic Press. 2016.

[2] Qafoku N. P., van Ranst, E., Noble, A. and Baes, G.: "Variable charge soils: their mineralogy, chemistry and management". Advances in Agronomy; 84. (2004) $170-172$.

[3] McBride, M. B.: "Environmental chemistry of soils". Ed. Oxford Univ. Oxford. 1994.

[4] Millán, F., Prato, J. G. García, M. Díaz, I. and Sánchez Molina, J. "Adsorción de iones $\mathrm{Cu}^{+2}$ y $\mathrm{Zn}^{+2}$ por materiales litológicos de carga variable, provenientes 
de suelos del estado Mérida, Venezuela”. Rev. Téc. Ing. Univ. Zulia, Vol 36, № 3 (2013) 195 - 201.

[5] Millán F., Prato, J. G., Zerpa, D. and Levei, E-A.: "Copper adsorption on calcined substrates from three granulometric fractions coming from two refractory variable charges lithological Materials". International Journal of Recent Development in Engineering and Technology. Vol 6, N 8, (2017) 7 - 17. (ISSN 2347-6435). http://www.ijrdet.com/ files/Volume6Issue8/IJRDET_0817_02.pdf

[6] Millán, F., Prato, J. G. and García, M.: “Characterization of oxidic litologic materials for ionic adsorption studies". "in extensu" Publication in Proceedings of XIX Congress of Venezuelan Soil Science Society. National Institute for Agronomical Research, INIA, Calabozo, Venezuela. 2011.

[7] Millán, F., Zerpa, D., Prato, J. G., Senila, M., Levei, E-A., Tanaselia, C. and Lomónaco, S.: "Caracterización química de tres fracciones granulométricas de materiales litológicos oxídicos". In extensu Publication in Proceedings of XXI Congreso de la Sociedad Venezolana de la Ciencia del Suelo, Instituto Nacional de Investigaciones Agronómicas, UNET, San Cristóbal. ISBN: 978-980-6300-94-1. http://www.unet.edu.ve/evento/suelos/files / Memorias_cvcs2015.pdf. 2015.

[8] Millán, F., Prato, J. G., López, Ma. A. and López, L.: "Estudio de la retención de iones calcio por materiales térmicamente modificados provenientes de suelos de la región de San Juan de Lagunillas, estado Mérida, Venezuela". Rev. Téc. Ing. Univ. Zulia, Vol. 32, № 1 (2009). 48 - 54.

[9] Prato, J. G., Millán, F., Pariata, A. and Fuentes, M.: Caracterización de materiales litológicos térmicamente modificados para la adsorción de iones $\mathrm{SO}_{4}^{-2}$ en aguas". Memorias X Congreso de la Sociedad Venezolana de Química, Universidad Simón Bolívar, Núcleo Vargas, Venezuela. 2011.

[10] Prato, J. G., Ortiz, L., Gómez, R., Millán, F., Palomares, A. E., Díaz, I. and Sánchez Molina, J.: "Evaluación de la adsorción de fosfatos de aguas naturales a partir de lechos preparados con suelo proveniente de Lomas Bajas, municipio Independencia, estado Táchira". Memorias XX Congreso Venezolano de la Ciencia del Suelo, Universidad Experimental de Los Llanos Centrales "Rómulo Gallegos", San Juan de Los Morros, Venezuela. 2013.
[11] Millán, F., Prato, J. G., Montilla, T. and Tănăselia, C.: "Using of variable charge adsorption beds for filtration of residual waters". Rev. Téc. Ing. Univ. Zulia, Vol 41, № 1 (2018) 98 - 110. (on line: http:// www.produccioncientifica.luz.edu.ve/index.php/ tecnica/).

[12] FitzPatrick, E. A.: Suelos: Su formación, clasificación y distribución. Editorial CECSA, México. 1985.

[13] Sakurai, K., Ohdate, Y. y Kyma, K.: "Comparison of salt titration and potentiometric titration methods for the determination of zero point charge (ZPC)". Soil Sci.Plant Nutr. 34 (1988) 171 - 182.

[14] Sposito G.: "The operacional definition of the zero point of charge in soils". Soil Sci. Soc. Am. J., № 45 (1981) 292-297.

[15] Castellan, G.: "Fisicoquímica". Fondo Educativo Interamericano, México. 1976.

[16] Castellan, G.: "Fisicoquímica: Problemas resueltos". Fondo Educativo Interamericano. 1982.

[17] Bareš, J., Černý, Č., Fried, V. and Pick, J.: “Collection of problems in physical chemistry". Addison - Wesley Pub. Co. Massachusetts. 1962.

[18] Tan, K. H.: "Principles of soil chemistry". 2nd ed. Marcel Dekker, Inc., New York. 1993.

[19] Adams, M.: "Fundamentos de química de suelos". Ed. CDCH, UCV, Caracas. 1995.

[20] Jiang, J., Xu, R. K., and Li, S-Z.: "Effect of ionic strength and mechanism of $\mathrm{Cu}$ (II) adsorption by Goethite and $\gamma-\mathrm{Al}_{2} \mathrm{O}_{3}$.' J. Chem. Eng. Data, 55, (2010) $5547-5552$.

[21] Yang, J. K., Lee, S. M., and Davis, A. P.: "Effect of background electrolytes and $\mathrm{pH}$ on the adsorption of $\mathrm{Cu}$ (II) /EDTA onto $\mathrm{TiO}_{2}$ ". J. Colloid Interface Sci. 295, (2006) $14-20$. 


\section{REVISTA TECNICA}

DE LA FACULTAD DE INGENIERIA

UNIVERSIDAD DEL ZULIA

Vol. 42. N`1, Enero - Abril 2019, pp. 02 - 45

Esta revista fue editada en formato digital y publicada en Diciembre de 2018, por el Fondo Editorial Serbiluz, Universidad del Zulia. Maracaibo-Venezuela

www.luz.edu.ve

www.serbi.luz.edu.ve

produccioncientifica.Iuz.edu.ve 